\title{
An Evaluation of Group Housing Affordability in Core Kolkata: The Case of Low-To-Middle Income Groups
}

\author{
Sen Chatterjee, Runa ${ }^{1}$ and Chatterjee, Bani $^{2}$ \\ ${ }^{1,2}$ Department of Humanities and Social Sciences, Indian Institute of Technology, Kharagpur; India. \\ 1runac73@gmail.com; ${ }^{2}$ bani@ hss.iitkgp.ernet.in
}

\begin{abstract}
The concentration of commercial and economic activities in the urban areas due to the increased pace of urbanization in developing nations, like India, has led to an increased migration to urban areas for livelihood opportunities. This has created severe pressure on urban housing. The demand supply balance is skewed across different price segments with demand outstripping supply in the affordable segment and excess supply in the luxury segment. In this context, the present paper aims to evaluate group housing affordability by low to middle income group of population (also referred to as 'Aspirers') in core Kolkata. The analyses have been carried out in three steps. First, the income-expenditure (Y-E), pattern of the target group have been studied to identify their affordability thresholds. Secondly, a relationship between the income expenditure pattern and group housing prices have been established through the affordability indices. Finally, the probability of owning a group housing unit in Kolkata has been evaluated from the probability of house ownership by Asset Holding Classes in urban West Bengal. The paper has established a basis for earmarking long-term policies on fixing the pricing pattern of future group housing ventures in Kolkata best matching the affordability pattern of the low-to-middle income group.
\end{abstract}

Key words: Group Housing affordability, low-to-middle income category, probability of group housing ownership, incomeexpenditure pattern, affordability indices.

\section{INTRODUCTION}

The increase in the pace of urbanization in developing nations, like India, has created an excess demand for urban housing in affordable segments. As the cities have emerged as the centres of commercial and economic activities, it has led to a tremendous rise in population in the cities and urban areas. However housing supply has not increased at a similar rate in these areas, for the rising population. The demand-supply balance has been skewed across different price and income 
segments. Demand has surpassed supply in the low-to-middle income categories, while there is an excess supply of luxury or premium housing for the higher-middle income and rich groups. Against this background, the present paper aims to assess the probability of group housing ownership by low-to- middle income group of households in Kolkata. In other words, the prime objective of this paper is to assess whether group housing is affordable by low to middle income households of Kolkata. In this study the target group whose housing affordability is being studied is the low-to-middle income group who are classified as 'Aspirers' in urban India by National Council of Applied Economic Research (NCAER). Group housing, besides the advantage of affordable price ranges due to advantages of physical agglomeration, also provides a repository of shared facilities and utilities, which appeals to the limited aspiration of low-to-middle income groups.

With the above aim, the study has been carried out in three steps. First, the nature of income-expenditure (Y-E) patterns of low to middle income group of population, residing in some of the group housing of Kolkata have been studied, based on which they have afforded as group housing dwelling unit. Secondly a relationship between the income expenditure patterns, as identified from the first step, and group housing prices of Kolkata have been assessed through the affordability indices. Finally, the probability of owning a group housing unit in Kolkata, has been evaluated from the probability of house ownership by Asset Holding Classes in overall urban West Bengal. It may be noted that West Bengal is a state in the eastern part of India and Kolkata is the capital city of West Bengal.

The paper first forwards a literature review on the fundamentals of affordability. Subsequently, the next three sections contains the methodology, analysis and its interpretation satisfying the three steps of examination.

By carrying out the examination, the paper has established a basis for earmarking long-term policies on fixing the pricing pattern of future group housing ventures in Kolkata best matching the changing affordability pattern of the low-tomiddle income groups, who are otherwise called 'Aspirers' exhibiting a limited but aspiring propensity for consumption and ownership of housing. 'Aspirers' have been classified as one of a four tiered income hierarchy proposed by National Council of Applied Economic Research (NCAER), Government of India. 


\section{OVERVIEW OF LITERATURE}

\subsection{Fundamentals of Housing Affordability}

The word 'affordability' generally means the ability to bear the expense of a commodity, or having the necessary money or other resources, or security of position to be able to purchase the concerned commodity (The Chambers Dictionary, 1998). In the present study, the commodity is 'housing', which is a basic necessity or infrastructure to sustain livelihood, i.e., life of individuals, families and communities. Housing affordability has become a common concept today. It epitomizes, in economic terms, nature of affording accommodation conditions. Several economists have defined housing affordability as a household's ability to pay housing costs without imposing constraints on living conditions. Economists have argued that any definition of housing affordability should implicate opportunity costs between housing and non-housing consumption, which is an essential aspect of affordability. Housing is usually considered affordable if it accounts for thirty percent (30\%) or less of a household's budget.

It is evident from literature that a majority of researchers like Feins and Lane (1981), Keare and Jimenez (1983), Kamath (1988), Miron (1989), Muelbauer (1990), ANHS (1991), and Bramley (1991) have defined housing affordability in terms of the 'Rule of Thumb'. The rule states that the housing expenditure is no more than thirty percent of a household's income. It may not be the case everywhere, especially in developing to underdeveloped urban economies. The other ideal definition is that of 'Housing Accessibility' (ANHS, 1991; Suchman, 1995; Wallace, 1995; Gyourko \& Tracy, 1999). It envisages a would-be homeowner's accessibility to homeownership if he/she has enough funds to pay down payment and closing costs requirements. However some of the recent studies considers some more parameters in defining housing affordability. According to the RICS Research Report (2010) affordability in the context of urban housing means provision of 'adequate shelter' on a sustained basis, ensuring security of tenure within the means of the common urban household. The KPMG Report on 'Affordable Housing - A Key Growth Driver in the Real Estate Sector', has defined affordable housing in terms of three main parameters, namely income level, size of dwelling unit and affordability. The report by the Task Force on 
Affordable Housing set up by the Ministry of Housing and Urban Poverty Alleviation (MHUPA) GOI (2012) defines affordable housing for various segments by size of the dwelling and housing affordability derived by the household income of the population. Affordable housing is defined on the basis of four criteria minimum volume of habitation, provision of basic amenities, cost of the house, location of the house. (Jones, 2012).

It is evident from preceding literature reviews that affordability has been often interpreted as the relationship between household income and housing expenditure. Housing becomes affordable if housing expenditure relative to income is reasonable or moderate. Affordability is commonly measured in terms of the ratio of housing costs to income. Over time, thresholds of the housing cost-to-income ratio have been set at 25 percent, 30 percent, 40 percent, and 50 percent. Households exceeding these cost burdens are identified as having an affordability problem. Accordingly, researchers have innovated on different processes of assessment in developed contexts.

Lerman and Reeder (1987) point out that a high cost-to-income ratio can be caused by a household's preference for large or luxurious housing. They therefore propose an affordability measure based on the cost of renting an appropriate amount of housing, as reflected in a standard basket of housing characteristics. The cost is obtained by using hedonic prices rather than actual rents. If the ratio of the cost to household income exceeds a certain threshold, then the household is viewed as having an affordability problem. The approach is of limited use when the cost of an appropriate amount of housing varies greatly across submarkets, and locations, because of market imperfections, and complex regulatory regimes. It also assumes that there is enough appropriate housing at average rents to meet the demand.

Thalmann (1999) proposes a measure that combines a rent-to-income ratio, a quality-based measure, and a measure of housing consumption. He suggests using the ratio of the average rent in the market for an appropriate bundle of housing and household income. Hedonic price estimates for various housing attributes are used to compute the average rent for an appropriate bundle of housing in a particular market. The measure is then used to develop a housing consumption metric that can distinguish between apparent affordability problems and actual affordability problems. Apparent affordability problem 
refers to a situation where the household consumes more than the standard housing bundle, and actual affordability problem is where the household either pays above average rents for the housing it consumes or the household has too little income to afford the standard housing bundle.

The distinction is significant in the cases of low-to-middle income groups, who are aspiring for home-ownership. Apparently, they are aspiring to own but 'actually' cannot. Higher income bracket supersede the implications of this distinction. Further, the affordability measure can highlight householders, who do not face affordability problems because they benefit from below market rents but could be susceptible in the future if they were forced to move out or if their rent discounts were discontinued.

Housing cost burden measures of affordability, however, do not consider whether the income available after the housing expenditure, is adequate to meet non-housing needs. Although most operational definitions of housing cost-burden supplement the cost-to-income ratio with some maximum limit on income for housing assistance programs, they do not distinguish between 1) the severity of the problem for households that are within the limit and have enough income left, after paying for housing, to meet non-housing needs and 2) those that do not. The measures proposed by Lerman and Reeder (1987) and Thalmann (1999) do not consider the actual financial constraints faced by low-to-middle income group households, many of which cannot afford to spend even 25 or 30 percent of their income on housing.

Stone (1990) has developed the notion of 'shelter poverty' as a measure of housing affordability problem. He pointed out that the conventional affordability measure understates the problem for families with children and other large families versus small families comprising of one and two person households. To address this difference, he defined shelter poverty as occurring when housing costs are so high that households cannot afford non-housing necessities. In this approach, the maximum amount available to spend on housing is the disposable income of the household minus the cost of a minimum adequate level of non-housing consumption. Consequentially, if a household pays more than the maximum, the measure indicates a shelter poor. 
Additionally, Stone (2006) has made an important observation on the need of iterative approaches to affordability measures. He states that in aggregate, housing affordability is not separable from housing standards or limits of supply like under-housing and over-housing. An analysis of affordability measures in terms of its extent and distribution and that taking into account other forms of housing deprivation would increase the number of households determined to have a true affordability problem, while adjustment for over housing would decrease it. Due to these offsetting tendencies, housing affordability measures should ideally be iterative. On the one hand, the approach should apply an economic affordability standard. On the other hand, or say, simultaneously, the approach should explore ways of enhancing the precision of analysis to account for under-housing and over-housing.

The Second Annual Demographia International Housing Affordability survey (Demographia, 2006) employs the 'Median Multiple' approach to measure housing affordability index, which is used to rate housing affordability. The 'Median Multiple' is given by the ratio of median house price to median household income. This approach has been used to evaluate affordability indices in the present study.

Kutty (2005) has introduced a new measure of housing affordability in the Indian perspective. It describes a situation that arises when a household, after paying for housing, cannot afford the poverty basket of non-housing consumption goods. He measures a severe form of the housing affordability problem. In the developing context, Kutty has termed it as 'housinginduced poverty'. The basket is assumed to be two-thirds of the official poverty line. Thus, a household at the poverty line would enter housing induced poverty if its housing expenditures exceed one-third of its income. Households above the poverty line can be reduced to housing-induced poverty if their housing costs are so high that their remaining income is less than twothirds of the official poverty line for a household of their size. Kutty's measure differs from Stone's (1990) measure in the sense that the normative minimum basket of non-housing goods, as proposed by Stone, is more generous than the basket implied in this new measure. 
Chen (2007) has listed three simple approaches to measure affordability from cases in China:

1. Price-to-income ratio

2. Mortgage payment to income ratio

3. Deposit-to-income ratio

Firstly, Chen's price-to-income ratio is the ratio of median (or mean) market price of a standardized housing unit to median (or mean) household or family income. Here income is disposable family income. However, in most cases it is available as before-tax income. Secondly, mortgage payment to income ratio is the ratio of standardized monthly housing debt service to disposable income. Finally, deposit-to-income ratio represents how many months of income is necessarily needed to have the down payment for a typical home mortgage. The three measures suggest straightforward approaches to affordability measures, but having certain deficiencies like lack of detailed desegregation, no inclusion of mortgage mechanisms, and lack of validity for reflecting the dual constraint of subjective decision and social sector norms of adequacy. The issue of housing affordability is not a simple problem of either too-high price or too-low-income levels. It is contingent upon both the subjectivity of consumers, and the social expectation and environment. In this context, Hancock (1993) had stressed the importance of distinguishing between the individual's personal conceptions of affordable housing from the aggregated or societal judgment.

Keeping in view the aforesaid approaches to measure housing affordability, there is an increasing number of scholars who are currently advocating other approaches that fit into any context, developed and developing. For instance, the residual income approach to measure 'Housing Affordability' is one such (Stone, 2006). The residual income approach argues that housing becomes a problem only when the income after housing expenditures, falls below the prescribed level of minimum socially acceptable or desirable non-housing consumption budget. In other words, a household has a housing affordability problem if it cannot meet its non-housing needs at some basic level of adequacy after paying for housing. The appropriate indicator of the relationship between housing costs and incomes is thus the difference between them, i.e., the residual income 
left after paying for housing; rather than the ratio. The present paper has also used the residual income approach to evaluate affordability indices.

In summary, it may be said that validity of various affordability measures are context specific i.e., specific to developed or developing economies, subject-specific i.e., based on private-funded or public-funded organizations, and are additionally varying as per realistic individual and societal yardsticks. In a majority of these measures, it is evident that the consumption or expenditure pattern has surfaced significantly forwarding the levels of indifferences between housing versus non-housing budgets, and the associated thresholds, margins or residuals of housing affordability.

\subsection{Bases of data: Secondary and Primary}

For the purpose of analysis both primary and secondary data have been used. Primary data have been collected from the study area, i.e., Kolkata. Kolkata is the capital city of West Bengal. West Bengal is a state located in the eastern region of India. West Bengal comprises of 2.7 percent of the total land area of India and supports $8 \%$ of the population of the country.

There is a substantial amount of research that stratifies Indian households based on their income. However, they are interpreted in terms of expenditure or consumption patterns. Rao and Natarajan (1996) of the National Council of Applied Economic Research (NCAER) have classified Indian consumers into five income segments or groups. The five segments are called 'Rich', 'Consuming Class', 'Climber', ‘Aspirants', and 'Destitute'. However in a later report of NCAER (Shukla, 2004) titled 'The Great Indian Middle Class' based on 2001-02 data, the classifications are called 'Rich', 'Middle Class', 'Aspirers', and 'Deprived', in which the share of 'Aspirers', as the low-to-middle income category in transition, is expected to increase over time (2005 - 2025) in Urban India (refer Figure 1). The present paper is based on the significance of an impact that the increasing share of low-to-middle income population [combined Aspirers and Low Middle income group - from 45\% (2005) to $66 \%$ (2025)] will have on the supply of affordable housing. 
Surveys were conducted on dwellers of group housing belonging to low to middle income groups. Luxury high end apartment complexes, condominiums and gated communities, i.e., group housing catering to the rich class, were kept outside the purview of the study. Group housing clusters were selected from both north and south of Kolkata, whose dwellers were the target group of this study, the 'Aspirers' or low to middle income group households. The survey area of the present study comprised of four group housing clusters of north and three of south Kolkata (refer Tables 1 to 4).

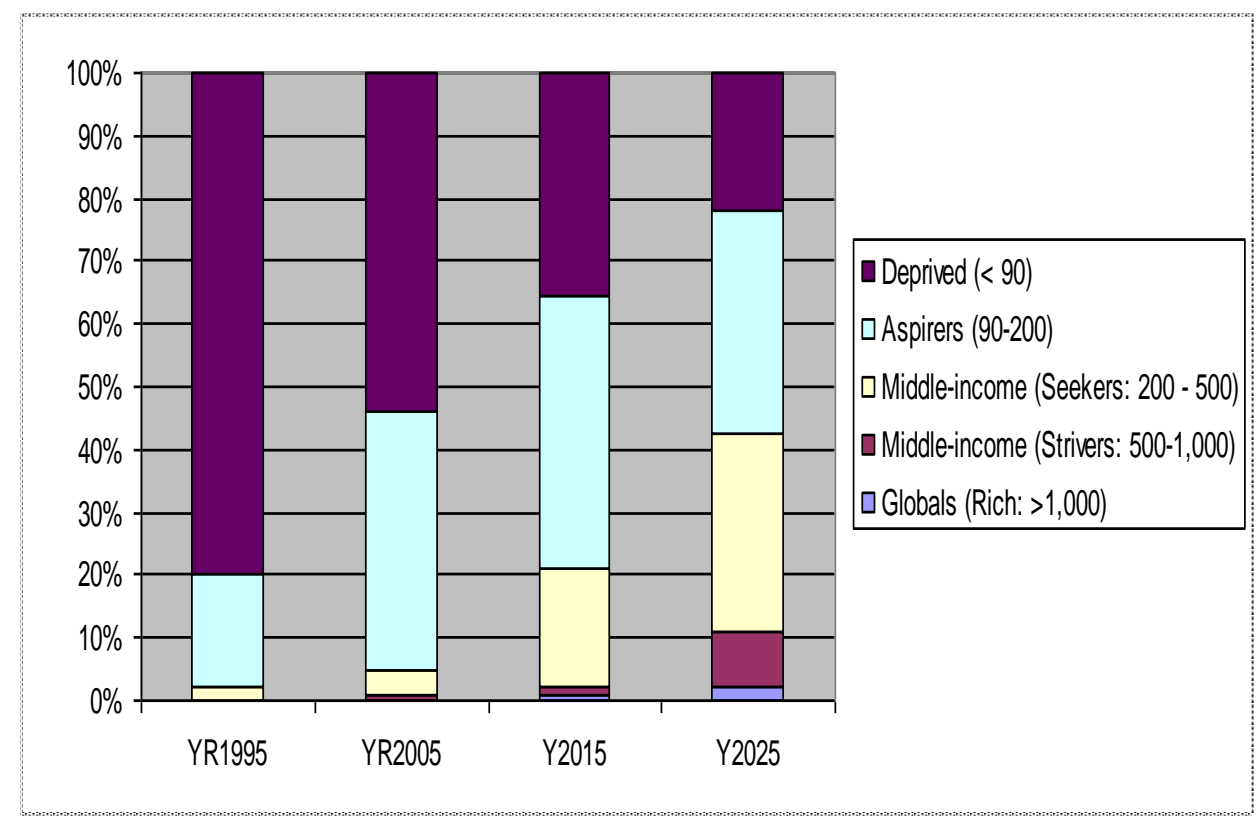

Figure 1: Urban Population distribution by annual distribution of income of four classes over time (1995-2025): 'Aspirers' represented in blue and Low-middle income group as yellow Source: NCAER Report (2005)

\section{METHODOLOGY}

\subsection{Methodology for studying the Y-E pattern of low-to-middle income group households in Kolkata}

Initially, from the primary data survey, the monthly income and monthly expenditure data were tabulated for every group housing cluster in North Kolkata, and South Kolkata. From the assorted primary data, category of Indian householders termed as 'Aspirers' by NCAER have been identified, and disaggregated. This identification was done on the basis of secondary data sources. The income groups have been defined based on the conventions used by NCAER (NCAER, 2005). 
The NCAER income groupings have been based on an all India study. Also the income groupings are as per the annual income. For the present analysis the monthly income figures have been computed from the annual income figures to make it comparable with the monthly expenditure figures of Kolkata. Expenditure classes have been taken from a KMDA study of Kolkata in 1997 (Chatterjee, Bhattacharya \& Halder, 1997). The expenditure class limits have been projected, using the Compounded Annual Growth Rate (CAGR), to get the expenditure data of 2005 . The prescribed CAGR is $1.35 \%$ (India Budget Report, 2005). The projection is based on the formula:

$$
P V=\left(1+\frac{r}{100}\right)^{n}
$$

where, $\mathrm{PV}=$ projected value, $\mathrm{r}=\mathrm{CAGR}$,

and, $\quad \mathrm{n}=$ number of years.

The results obtained have been compared with the primary data.

\subsection{Methodology for assessment of affordability indices}

This study has adopted the Median Multiple approach as one of the methods to calculate housing affordability index of group housing dwellers in Kolkata. The index is the ratio of median house price to median household income. It is given by the formula:

Median Multiple = Median house price / Median household income

The Annual Demographia International Housing Affordability survey (Demographia, 2006) has set some thresholds of housing affordability ratings. The ratings are as given in Table 1:

Table 1: Ratings of Affordability

\begin{tabular}{ll}
\hline Ratings & Median Multiple \\
\hline Severely Unaffordable & 5.1 \& over \\
Seriously Unaffordable & 4.1 to 5.0 \\
Moderately Unaffordable & 3.1 to 4.0 \\
Affordable & 3.0 or less \\
\hline
\end{tabular}

Source: Demographia (2006) 
The Median Multiple affordability index was calculated both at the buyer's price and the current prevailing market price. The median buyer's price was estimated from the prices, revealed by buyers, at their time of purchase. The median price was calculated for each housing cluster separately. The current price was calculated by multiplying the current rate per square feet with the area of the dwelling unit. The median household income was taken as revealed on the date of the survey. The median household incomes were calculated for each housing cluster separately.

The other method to assess housing affordability index is Residual Income approach, which measures the income left after burdens of housing expenditures. It is given by the formula:

Residual Income $(\mathrm{R})=$ Annual Income $(\mathrm{Y})-$ Housing Price $(\mathrm{P})$

Residual income (R) is expected to be the income left after paying for housing. The method of residual income exposes the sheer inability to afford non-housing expenses, once one-time annual down payment of total housing price arises. In reality, however a practice of payment schedule based on Equal Annual Installments (EAIs) is prevalent. EAI is based on accepted norms or current practices in the housing market, shared by both private and public developers. From secondary sources, and primary verifications four EAIs are usually found to be evident. Hence each EAI = Total house price/4 For the purpose of calculating the residual income $(\mathrm{R})$, the following formula is applicable:

The residual income $(\mathrm{R})=$ Annual $\mathrm{Y}-$ Fraction of payment schedule as EAI

\subsection{Methodology for assessment of probability of group housing ownership}

To address the prime objective of the paper, the probability of housing asset ownership by ten Asset Holding Classes (AHC) of urban West Bengal has been conducted. The study leads to an understanding of affordability situation of an AHC, where assets are inclusive of housing. Housing affordability is assumed to follow a non-linear relationship with asset holding. As logit model captures such non-linear distribution, it has been used for calculation of probability. 
Data on households of urban West Bengal are grouped according to their asset holding class. The numbers of households owning a house at each asset holding class have been taken from NSSO 59th round (Government of India, 2003), Report no. 500. Corresponding to each AHC $\left(X_{i}\right)$, there are $N_{i}$ households, $n_{i}$ among whom are home owners $\left(n_{i}<=N_{i}\right)$. Therefore: $P_{i}=n_{i}$ / $\mathrm{N}_{\mathrm{i}}$.

For calculation of probability a binary response model;i.e., logit model is used. The binary response can actually vary in three following ways in favor of either owning or not owning a house. The three-way variation is the key to the distribution of probability assessment. First, Yi = 0, which represents null or no ability to afford housing ownership; second, Yi $=1$ that stands for full affordability of housing ownership; third, other values of probability that are intermediary or transitional i.e., values which are neither 0 or 1 , but intermediary or transitional values that fall between 0 and 1 . Logically these intermediary values are expected to represent the probability distribution $(\mathrm{P})$ of housing ownership conforming to incomeexpenditure patterns that are neither very high nor very low.

The intermediary or transitional range is represented by: $0 \leq \mathrm{E}\left(\mathrm{Y}_{\mathrm{i}} \mid \mathrm{X}_{\mathrm{i}}\right) \leq 1 . \mathrm{E}\left(\mathrm{Y}_{\mathrm{i}} \mid \mathrm{X}_{\mathrm{i}}\right)$ gives the probability of a household owning a house whose AHC is $\mathrm{X}_{\mathrm{i}} \cdot \mathrm{P}_{\mathrm{i}}=$ probability that $\mathrm{Y}_{\mathrm{i}}=1$, i.e., where the event of ownership occurs, and (1- $\left.\mathrm{P}_{\mathrm{i}}\right)$ $=$ probability that $Y_{i}=0$, i.e., the event of ownership does not occur.

For the final estimation purpose, the Logit Model is therefore represented as:

$\mathrm{L}_{\mathrm{i}}=\ln \left(\mathrm{P}_{\mathrm{i}} / 1-\mathrm{P}_{\mathrm{i}}\right)=\beta_{1}+\beta_{2} \mathrm{X}_{\mathrm{i}}+\mu_{\mathrm{i}}=\mathrm{Z}_{\mathrm{i}} \quad$ (equation 1), where:

- $\mathrm{L}_{\mathrm{i}}$ is the $\log$ of the odds-ratio $=\left(\mathrm{P}_{\mathrm{i}} / 1-\mathrm{P}_{\mathrm{i}}\right)$

- $\beta_{1}$ is the intercept or the value of the log-odds in favor of owning a house if income or equivalent levels of $\mathrm{AHC}$ value is zero

- $\beta_{2}$ is the slope that measures the change in $\mathrm{L}_{\mathrm{i}}$ for a unit change in income or equivalent levels of $\mathrm{AHC}$ value 
Since the available data are grouped data in the present research, the grouped logit (GLOGIT) model is used. Here one cannot apply ordinary least squares (OLS) as the disturbance term in the logit model is heteroscedastic. Thus weighted least squares (WLS) will have to be used. To resolve the problem of heteroscedasticity equation 1 can be written as:

$$
\sqrt{w_{i}} \mathrm{~L}_{\mathrm{i}}=\beta_{1} \sqrt{w_{i}}+\beta_{2} \sqrt{w_{i}} \mathrm{X}_{\mathrm{i}}+\mathrm{u}_{\mathrm{i}} \quad \text { (equation 2) }
$$

\section{RESULTS AND ANALYSIS}

\subsection{Y-E pattern of low-to-middle income group households in Kolkata}

In this section the Y-E patterns of low to middle income group households, residing in some of the group housing of Kolkata, is given. Table 2 provides data on Monthly Income (MI) of all surveyed households in North Kolkata. Table 3 has provided complementary data on Monthly Expenditure (ME). It is observable from Table 2 that two lower ranges of MI $(1+2)$ cumulates to around $67.6 \%$ of the total sample households surveyed in North Kolkata. As the surveyed households are group housing owners it has been assumed that they do not belong to the deprived category as per NCAER classification. The two lower ranges are Rs. 5000-9999, and Rs. 10000-14999. It is observable that the two ranges collectively (Rs 5000-14999) approximately correspond to NCAER's benchmark of 'Aspirers', whose upper limit of Monthly Income MI is Rs. 16,666. It implies that the majority of dwellers in North Kolkata i.e., around $67 \%$ are not 'Middle class', but 'Aspirers'.

The picture changes in South Kolkata. Table 4 provides data on Monthly Income (MI) of all group housing dwellers in South Kolkata. Table 5 has provided complementary data on Monthly Expenditure (ME).

Table 2: Data on Monthly Income (MI) of all surveyed households in North Kolkata

\begin{tabular}{|c|c|c|c|c|}
\hline \multicolumn{3}{|c|}{$\begin{array}{l}\text { Ranges of Monthly } \\
\text { Income (Rs.) }\end{array}$} & Percent & $\begin{array}{l}\text { Cumulative } \\
\text { Percent }\end{array}$ \\
\hline$\overline{1}$ & $5000-9999$ & 16 & 23.5 & 23.5 \\
\hline 2 & 10000-14999 & 30 & 44.1 & 67.6 \\
\hline 3 & $15000-24999$ & 21 & 30.9 & 98.5 \\
\hline \multirow[t]{2}{*}{4} & 25000-49999 & 1 & 1.5 & 100.0 \\
\hline & Total & 68 & 100.0 & \\
\hline
\end{tabular}


Table 3: Data on ranges of Monthly Expenditure (ME) of all

\begin{tabular}{lrrrr} 
& \multicolumn{4}{c}{ surveyed households in North Kolkata } \\
\hline $\begin{array}{l}\text { Ranges of Monthly } \\
\text { Expenditure (Rs) }\end{array}$ & Frequency & Percent & $\begin{array}{r}\text { Cumulative } \\
\text { Percent }\end{array}$ \\
\hline 1 & $0-4999$ & 11 & 16.2 & 16.2 \\
2 & $5000-9999$ & 42 & 61.8 & 78.0 \\
3 & $10000-14999$ & 15 & 22.1 & 100.0 \\
\hline & Total & 68 & 100.0 & \\
\hline
\end{tabular}

Table 4: Data on Monthly Income (MI) of all surveyed households in South Kolkata

\begin{tabular}{|c|c|c|c|c|}
\hline \multicolumn{4}{|c|}{ Monthly Income (Rs) } & $\begin{array}{r}\text { Cumulative } \\
\text { Percent }\end{array}$ \\
\hline 1 & $5000-9999$ & 22 & 33.3 & 33.3 \\
\hline 2 & $10000-14999$ & 15 & 22.7 & 56.0 \\
\hline 3 & $15000-24999$ & 22 & 33.3 & 89.3 \\
\hline 4 & 25000-49999 & 7 & 10.6 & 100.0 \\
\hline & Total & 66 & 100.0 & \\
\hline
\end{tabular}

Table 5: Data on ranges of Monthly Expenditure (ME) of all surveyed households in South Kolkata

\begin{tabular}{llrrr}
\hline $\begin{array}{l}\text { Ranges of Monthly } \\
\text { Expenditure (Rs) }\end{array}$ & Frequency & Percent & \multicolumn{2}{c}{$\begin{array}{c}\text { Cumulative } \\
\text { Percent }\end{array}$} \\
\hline 1 & $0-4999$ & 3 & 4.5 & 4.5 \\
2 & $5000-9999$ & 23 & 34.8 & 39.3 \\
3 & $10000-14999$ & 21 & 31.8 & 71.1 \\
4 & $15000-24999$ & 19 & 28.8 & 100.0 \\
\hline \multicolumn{4}{r}{} & \multicolumn{3}{l}{ Total } & 66 & 100.0 & \\
\hline
\end{tabular}

First, in South Kolkata the percentage of 'Aspirers' in terms of Monthly Income and Monthly Expenditure are $56 \%$ and $39.3 \%$, respectively. It is less compared to North Kolkata. Additionally, the data has an uppermost range of expenditure class, i.e., Rs. 15000-24999 (refer Table 5). It indicates higher income-expenditure ranges in South Kolkata. The reasons can be many. Some can be attributed to better economic standards, and, a relatively modern history of group housing in South Kolkata. Housing situations in South Kolkata, also reveal relatively better physical-environmental standards, and greater accessibility to high-end services. It is evident from Table 3 that a large share of $78 \%$ of dwellers in north Kolkata are 'Aspirers' as per ME. The upper limit of ME of the 'Aspirers' is Rs.9999.

The inference is that, by a comparative assessment of income-expenditure patterns based on primary data, it was possible to identify the nature of income and expenditure pattern of the 'Aspirer' group of population in Kolkata. This has helped in finding the exact income range with which this group of population can purchase a house. The examination of 
income and expenditure pattern is required so that should there be any inconsistency in the income data, it can be cross checked from the expenditure side also. A majority of group housing dwellers have been identified as 'low-to-middle' income groups or Aspirers, in Kolkata, particularly in the north.

\subsection{Assessment of Affordability Indices}

The present section has assessed the affordability indices, which gives a relationship between Y-E pattern, (as identified in the previous section), and group housing prices. The extent of affordability is assessed in terms of affordability indices. First, the paper evaluates affordability indices based on Median Multiple Approach. The median multiple at the original buyer's price is listed in Table 6. From Table 6 it is observable that both in north and south of Kolkata, group housings are largely affordable at original buyer's price. However in case of north Kolkata, Cluster 1 are moderately unaffordable, and Cluster 2 apartments are seriously unaffordable, as revealed during survey. Cluster 1 and Cluster 2 in North Kolkata were the predominant cases of mortgage purchase where buyers still have a loan burden at the time of survey.

Table 6: Affordability Indices Based on Median Multiple (At Buyer's Original Price)

\begin{tabular}{rrrr}
\hline $\begin{array}{l}\text { Broad } \\
\text { Location }\end{array}$ & \multicolumn{2}{c}{$\begin{array}{c}\text { Name of } \\
\text { Housing }\end{array}$} & \multicolumn{2}{c}{$\begin{array}{l}\text { Median multiple } \\
\text { at buyer's price }\end{array}$} & \\
\hline North & Cluster 1 & 3.33 & Moderately Unaffordable \\
Kolkata & Cluster 2 & 4.17 & Seriously Unaffordable \\
& Cluster 3 & 1.67 & Affordable \\
& Cluster 4 & 2.33 & Affordable \\
\hline & Total North & 2.67 & Affordable \\
\hline Kolkata & Cluster 1 & 0.26 & Affordable \\
& Cluster 2 & 1.80 & Affordable \\
& Cluster 3 & 3.40 & Moderately Unaffordable \\
\hline & Total South & 2.86 & \\
\hline
\end{tabular}

In south Kolkata, Cluster 1 housing complex is an interesting case. It was constructed during 1982-83. Over the years, most of the homeowners have been raised to higher income levels. As median multiple has been estimated, with original 1982- 
83 prices, and income levels as on the date of survey, the situation appears highly affordable. Similar is the case with Cluster 2, which was built during 1996-97. However, the affordability situation is different for Cluster 3 housing complex, which was constructed after the year 2000. Hence Cluster 3 housing complex, being a case of mortgage ownership, reveals a situation where the households had the loan burden at the time of survey.

It is natural that every household aspires for a better standard of living. A house is a prime indicator of a householder's standard of living. During the survey, it was revealed that many of the households were living in their present apartments due to budget constraints. At the same time, it was also observed that due to increase in their economic standards, some households aspired for better apartments. To address the issue of variations in group housing affordability, Affordability Indices using the median multiple method, were calculated at current prices. The results are given in Table 7.

From Table 7, the median multiple at current prices, in north Kolkata, indicate that most of the houses are unaffordable. Also for south Kolkata a similar picture emerges except for Cluster 1 housing complex. It is mainly due to the fact that house owners in Cluster 1 have over time, moved to higher economic levels. Hence for the dwellers in Cluster 1, the situation appears affordable.

It is observed that group housing units were mostly affordable when purchased but for most of these group housing projects, the housing would not be affordable if purchased by same households at current values. This is mainly due to the rapid pace of urbanization which has pushed up the demand for housing units. The supply falls short of this increased demand thereby pushing up prices sharply. Property prices have risen faster than income levels. Hence if households had to purchase their present group housing dwelling unit at current prices, it would give rise to an unaffordable situation. To remedy this issue policy interventions are necessary to bridge the gap between demand and supply of housing and increase the supply of housing at a faster rate at affordable prices. 


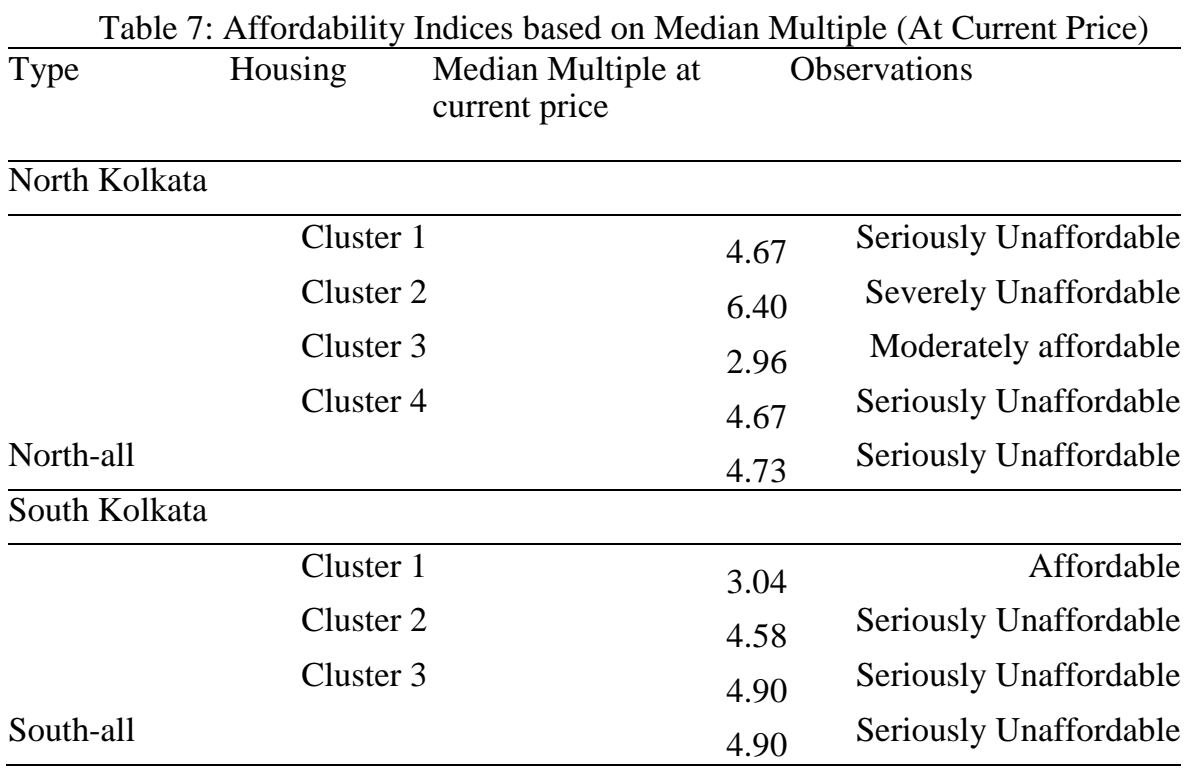

Next, the estimates of affordability indices were evaluated based on residual income approach. The residual income approach arises from the recognition that the cost of housing makes the largest and least flexible claim on after-tax income for most households. In other words, non-housing expenditures are limited by how much is left after paying for housing. It means that a household has a housing affordability problem if it cannot meet its non-housing needs at some basic level of adequacy after paying for housing. The appropriate indicator of the relationship between housing costs and incomes is thus the difference between them. This is the 'residual' income. It is a better rationale of affordability, compared to different ratio approaches.

Table 8 has forwarded Affordability Indices (AI) based on the residual income approach. It is evident that Cluster 1 housing complex in South Kolkata is an exception due its longer ownership history. In the context of old price levels, and histories of slow payment schedules, the significance of the residual factor diminishes in its case. On the contrary, for others, the situation is $\mathrm{R}<\mathrm{E}$. Only in Cluster 3 of North Kolkata, R exceeds E marginally. Thus the method of residual income exposes the sheer inability to afford non-housing expenses once one-time annual down payment of total housing price arises. 
Table 8: Affordability Indices based on Residual Income method

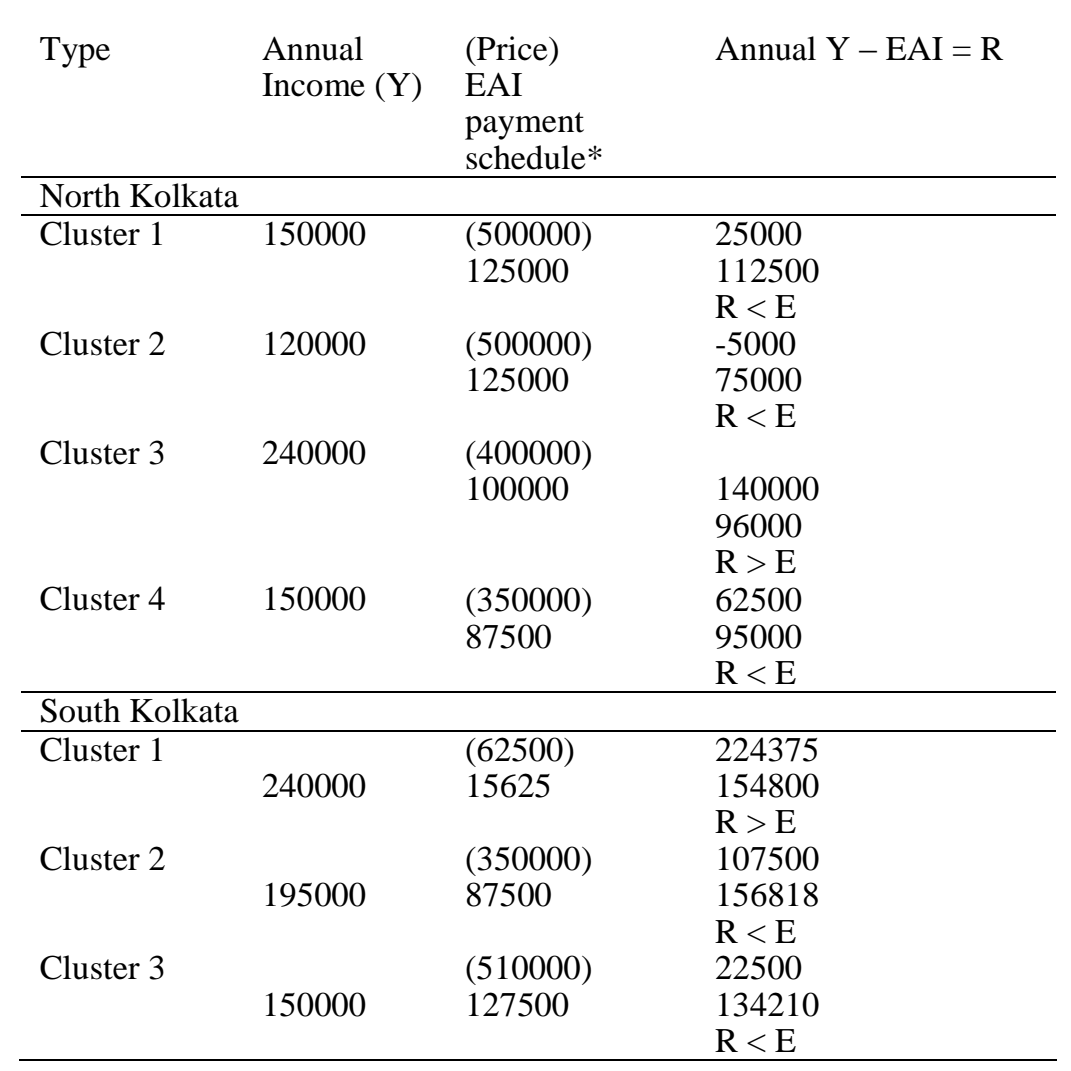

\subsection{Probability of Group Housing Ownership}

The estimates of probability of house ownership are presented in Table 9. In Table 9 the data in column (2) denotes the midpoints of different levels of household AHC (Xi). Column (3) represents the number of households belonging to each level of AHC (Ni). For the probability calculation, data on number of households owning a house within each Ni is taken and is represented by $\mathrm{n}_{\mathrm{i}}$, which is given in column (4). Columns (5) and (6) forward the estimated results of Logit, and probability .

From the analysis of grouped secondary data, the results on probability of home ownership have been estimated. The probability estimates of house ownership over the ten levels of AHC in urban West Bengal indicates that the probability of owning a dwelling unit has gone up from 0.4779 in AHC no. 1 to 0.9991 in AHC no. 10. It means that the probability of owning a house asset increases from a little below 50\% from AHC no.1 to almost $100 \%$ when the householder belongs to AHC no. 10 . 
The results however provide a general explanation as the nature of housing asset, based on stated values of housing assets in Table 11, may not guarantee the ownership of a group housing unit having a fairly livable condition.

Table 9: Estimates of Probability of House Ownership

\begin{tabular}{llllll}
\hline AHC & $\begin{array}{l}\mathrm{X}_{\mathrm{i}} \\
\text { (in Rs } \\
\text { (000) }\end{array}$ & $\mathrm{N}_{\mathrm{i}}$ & $\mathrm{n}_{\mathrm{i}}$ & Logit & Probability \\
$(1)$ & $(2)$ & $(3)$ & $(4)$ & $(5)$ & $(6)$ \\
\hline 1 & 7.5 & 755 & 134 & -0.08845 & 0.47790 \\
2 & 22.5 & 284 & 142 & 0.01085 & 0.50271 \\
3 & 45 & 324 & 201 & 0.1598 & 0.53987 \\
4 & 80 & 396 & 312 & 0.3915 & 0.59664 \\
5 & 125 & 399 & 312 & 0.6894 & 0.66583 \\
6 & 175 & 268 & 235 & 1.0204 & 0.73505 \\
7 & 250 & 417 & 370 & 1.5169 & 0.82008 \\
8 & 375 & 381 & 354 & 2.3444 & 0.91249 \\
9 & 625 & 509 & 494 & 3.9994 & 0.98200 \\
10 & 1075 & 399 & 393 & 6.9784 & 0.99907 \\
\hline \multicolumn{7}{c}{4132} \\
\end{tabular}

Source: NSS Survey Report (Government of India, 2003)

The probability of owning a group housing asset specifically begins in the last three levels, i.e., AHCs no. 8, 9 and 10 and their probability estimates are $0.9125,0.9820$ and 0.9990 , respectively. This is mainly due to the fact that the values of housing assets, given in column number (1) of Table 11, for AHC no. 8, 9 and 10, correspond to prices of group housing, as revealed by primary data. In other words, based on stated values of housing assets in Table 11, it can be said that the housing asset owned by AHCs no. 8, 9 and 10 could realistically imply owning a group housing asset. The commensuration between the values of housing assets, given in column number (1) of Table 11, and the price of group housing units as revealed by primary data validates a threshold of group housing affordability.

The threshold of group housing ownership stands out in the last three AHC only, as compared to lower AHCs nos. 1 to 7. The estimated model is statistically significant at $5 \%$ level. Also the estimated model has reasonably high explanatory power. The AHCs have a statistically significant positive impact on house ownership (refer Table 10). This means that higher the Asset Holding Class of a household, higher is the probability of owning a group housing asset. 


\begin{tabular}{lrr} 
& Table 10: Statistical Validation of Results in Table 9 \\
\hline Variable & Co-efficients & $\mathrm{t}-$ Stat \\
\hline${\sqrt{\mathrm{w}_{\mathrm{i}}}}$ & -0.13810 & -0.35856 \\
$\mathrm{X}_{\mathrm{i}}{ }=\mathrm{X}_{\mathrm{i}} \cdot{ }_{\mathrm{w}_{\mathrm{i}}}$ & 0.00662 & $3.51515^{*}$ \\
Adjusted R Square & & 0.50855 \\
$\mathrm{~F}-$ Stat & & $8.28 * *$ \\
Number of Observations & & 10 \\
\hline
\end{tabular}

Note: * Statistically significant at $1 \%$ level.

** Statistically significant at $5 \%$ level.

Table 11: Percentages of Average Values of Housing Assets (V-HA) and Non-Housing Assets (V-N-HA) in Average Values of Total Assets (V-TA) as per the Ten Levels of Xi or AHC in Urban West Bengal

\begin{tabular}{llll}
\hline $\begin{array}{l}\mathrm{X}_{\mathrm{i}} \\
\text { (in Rupees } \\
\text { '000) }\end{array}$ & $\begin{array}{l}\text { V-HA (\%) } \\
\text { (in Rupees) }\end{array}$ & $\begin{array}{l}\text { V-N-HA (\%) } \\
\text { (in Rupees) }\end{array}$ & $\begin{array}{l}\text { V-TA } \\
\text { (in Rupees) }\end{array}$ \\
(AHC) & $(1)$ & $(2)$ & $(3)$ \\
\hline 7.50 & $895(16.2)$ & $4618(83.8)$ & 5513 \\
22.5 & $5298(24.7)$ & $16151(75.3)$ & 21449 \\
45.0 & $12244(28.4)$ & $30809(71.6)$ & 43053 \\
80.0 & $24632(31.1)$ & $54652(68.9)$ & 79284 \\
125.5 & $37709(30.4)$ & $86270(69.6)$ & 123979 \\
175.0 & $61570(35.4)$ & $112472(64.6)$ & 174042 \\
250.0 & $93547(38.8)$ & $147247(61.2)$ & 240794 \\
375.0 & $157669(43.0)$ & $209846(57.0)$ & 367515 \\
625.0 & $253940(42.5)$ & $343382(57.5)$ & 597322 \\
1075.0 & $575033(37.5)$ & $960051(62.5)$ & 1535084 \\
\hline \multicolumn{7}{l}{ Avg value of assets - all households $(=41460)$} & 322023
\end{tabular}

It may be noted that in the state of West Bengal, the probability of owning a housing asset is in the highest three

AHCs. However the value of the housing asset correspond to values of group housing prices for low to middle in come group.

Thus the percentage of population belonging to the richer class in the state is negligible and their presence is not observed in

Table 11. In the last decade both the public, private and even joint ventures have added to the housing supply of the richer class due to high profitability. Nothing much has been done for the 'Aspirer' group of population and they are almost forced to move out of city limits due to the high cost of living in the city, or sometimes compromise with sub standard and inadequate shelter. Hence there is a great need of policy intervention for investing in housing for the masses.

\section{CONCLUSIONS}

The findings have revealed a significant threshold of income-expenditure pattern, among the population of Kolkata,

which has been earmarked as 'Aspirers' by a National Council of Applied Economic Research study (2005). Secondly, significant variations in affordability have been found between group housing dwellers of north Kolkata as compared to south 
Kolkata. Third and finally, the probability of house ownership by the low-to-middle income-expenditure pattern of group housing dwellers in Kolkata has been found to be high in the case of the two uppermost Asset Holding Classes of overall Urban West Bengal thereby revealing a minimal share of high income groups in Kolkata and consequently, re-orienting the attention to the 'low-to-middle income groups'.

The paper recommended means of improvements in group housing affordability having a contributing impact on the urban economy of Kolkata. The paper also suggests innovative group housing policies assuring lower house prices and their availability to the urban majority representing low-to-middle income groups. On the whole, the study has highlighted the need of streamlining and reinforcing the supply of affordable group housing to the low-to-middle income urban masses. The paper further recommends that the supply has to accommodate the housing demand based on current paces of urbanization in Kolkata.

The paper has initiated a process of assessment of group housing affordability as governed by specific thresholds of income and expenditure patterns of its dwellers in Kolkata. The study has identified a significant low-to-middle income threshold, which has been earmarked as 'Aspirers' by NCAER studies and further corroborated by recent assessment by premium housing research organizations like RICS-Research (2010) and Jones (2012) in India as the 'right beneficiaries'.

It is a significant finding based on the present examination by the paper, through which the relationship between quantitative and qualitative aspects of group housing affordability and group housing values can be better understood, broadly. Also, specific socio-economic potentials of mass or 'Group housing' can be truly recognized as a key supply area in the future of Indian housing market based on affordable price fixation and market demand based on an understanding of the dynamism (over time) of group housing ownership by the 'right beneficiaries' earmarked as low-to-middle income based 'Aspirers'. 


\section{ACKNOWLEDGMENTS}

We would like to thank official members of different housing associations in Kolkata. We would also like to thank the dwellers of seven chosen clusters of housing in Kolkata, whose inputs and preferences have contributed to the present body of research.

\section{REFERENCES}

Australia National Housing Strategy (ANHS), (1991). The affordability of Australian housing. Issues Paper No. 2, Canberra, Australian Government Public Service (AGPS).

Bramley, G. (1991). Bridging the affordability gap in 1990: An update of research on housing access and affordability. Bristol, University of Bristol: SAUS.

Chatterjee, N., Bhattacharya, N. and Halder, A. (1997). Socio-economic profile of households in Calcutta metropolitan area: 1996-97, Calcutta, Calcutta Metropolitan Development Authority.

Chen, J. (2007). Lecture for Housing Affordability. Graduate Level Real Estate Economics. Sweden: Uppsala University.

Demographia. (2006). Second annual demographia international housing affordability survey: 2006.

Feins, J. D. \& Lane, T. S. (1981). How much for housing? A new perspective on affordability and risk.Cambridge, Massachusetts: Abt Books.

Government of India. (2003). Households assets and liabilities in India. Report no. 500, NSS 59 ${ }^{\text {th }}$ Round. National Sample Survey Office (NSSO), Ministry of Statistics and Programme Implementation. The Government of India: New Delhi.

Gyourko, J., \& Tracy, J. (1999). A look at real housing prices and incomes: Some implications for housing affordability and quality. Economic Policy review, 5(3), 63-77.

Hancock, K. E. (1993). Can pay? Won’t pay? Or economic principles of affordability. Urban Studies, 30(1), $127-145$.

Jones L. L. (2012). Affordable housing in India: an inclusive approach to sheltering the bottom of the pyramid. On.Point.

Kamath, R. (1988). The Measurement of Housing Affordability, Real Estate Issues, Fall/Winter, pp. 26-33.

Keare, D. H. \& Jimenez, E. (1983). Progressive development and affordability in the design of urban shelter projects, Washington, DC: World Bank.

KPMG in India, (2010). Affordable Housing - A key growth driver in the real estate sector. 
Kutty, N. K. (2005). A new measure of housing affordability: Estimates and analytical results. Housing Policy Debate, 16(1), 113-142.

Lerman, D. L. \& Reeder, W. J. (1987). The affordability of adequate housing. The American Real Estate and Urban Economics Association (AREUEA) Journal, 15(4), 389-404.

MHUPA, GOI, (2012). Task force report on promoting affordable housing. Ministry of Housing and Urban Poverty Alleviation, Government of India: New Delhi.

Miron, J. R. (1989). Household formation, affordability and housing policy. Population Research and Policy Review, 8, 55 77.

Muelbauer, J. (1990). The housing market and the UK economy: Problems and opportunities. In J. Ermisch (Ed.), Housing and the National Economy. Aldershot: Gower.

National Council of Applied Economic Research (NCAER). (2005). The Great Indian Market: Results from the NCAER's Market Information Survey of Households. National Council of Applied Economic Research: New Delhi.

Rao, S. L., \& Natarajan, I. (1996). Indian market demographics: The consumer classes. US: Global Business Press.

RICS-Research, (2010). Making affordable housing work in India, Research Report, November 2010, Ministry of Housing and Urban Poverty Alleviation, Government of India.

Shukla, R. K., Dwivedi, S. K., \& Sharma, A. (2004). The great Indian middle class: Results from the NCAER market information survey of households.

Stone, M. E. (1990). One third of a nation - A new look at housing affordability in America, Washington, DC: Economic Policy Institute.

Stone, M.E. (2006). What is housing affordability? The Case for the residual income approach, Housing Policy Debate, 17(1), 151-184.

Suchman, D. R. (1995, March). Manufactured housing: An affordable alternative (Working Paper). Washington, DC: The Urban Land Institute

Thalmann, P. (1999). Identifying households which need housing assistance. Urban Studies,36(11), 1933-1947.

The Chambers Dictionary. (1998). The Chambers Dictionary ( $1^{\text {st }}$ ed.). New Delhi, India: Allied Chambers (India) Ltd.

Wallace, J. E. (1995). Financing affordable housing in the United States. Housing Policy Debate, 6(4), 785-814. 